\title{
OCJENA RAZVITKA BANKOVNIH OSIGURANJA U REPUBLICI HRVATSKOJ
}

Cilj ovog rada je usporediti i ocijeniti razvijenost bankovnih osiguranja, kao modela suradnje banaka i osiguravajućih društava u distribuciji proizvoda osiguranja putem banaka, u izabranim europskim državama i u Republici Hrvatskoj. Uz navedeno, u radu se prikazuju teorijske značajke bankovnih osiguranja te navode prednosti i nedostaci bankovnih osiguranja. Za razliku od razvijenih europskih država, gdje životna osiguranja distribuirana putem bankovnih osiguranja čine preko $60 \%$ udjela u zaračunatoj premiji životnih osiguranja, na hrvatskom tržištu taj udjel iznosi oko $36 \%$ iz čega se zaključuje kako je tržište bankovnih osiguranja u Republici Hrvatskoj još uvijek nerazvijeno te ima veliki potencijal daljnjeg rasta. Usporedbom zaračunate premije zaključuje se kako se bankovno osiguranje brže razvija u području životnih osiguranja, a sporije u području neživotnih osiguranja. To je u skladu s trendom i strukturom u ostalim razvijenim europskim zemljama.

Ključne riječi: banke, osiguravajuća društva, bankovno osiguranje, Republika Hrvatska

\footnotetext{
* Matija Ploh, univ.spec.oec., analitičar, HAMAG - BICRO - Hrvatska agencija za malo gospodarstvo, inovacije i investicije (E-mail: matijaploh87@gmail.com).

Ovaj rad ni na koji način ne predstavlja stajalište HAMAG-BICRO-a na temu „Ocjena razvitka bankovnih osiguranja u Republici Hrvatskoj“ te isključivo prezentira osobne stavove autora rada.

Rad je primljen u uredništvo 14.09.2017. godine, a prihvaćen je za objavu 13.06.2018.
} 


\section{Uvod}

Pod utjecajem deregulacije, informatizacije, internacionalizacije, globalizacije u financijama, spajanju i konvergenciji financijskih institucija, harmonizaciji regulatornih okvira i drugih važnih promjena, financijski sustavi se transformiraju od tradicionalnih „bankovno-dominirajućih“ u „tržišno-orijentirane“ sustave (Leko, 2005a, str. 115). U takvim novim okolnostima i izazovima u okruženju, najveći broj banaka se preoblikovao od tradicionalnih depozitno-kreditnih institucija u banke ,potpune usluge“ sposobne pružiti svaku financijsku uslugu (Leko, 2005b). U uvjetima pada profitabilnosti i konkurentnosti, banke nastoje ostvarivati što više nekamatnih prihoda u ukupnim prihodima kako bi povećale profitabilnost i uspješnost poslovanja. Za razliku od banaka, kao depozitno-kreditnih financijskih institucija, osiguravajuća društva pripadaju skupini nebankovnih, nedepozitnih i nekreditnih financijskih institucija. Kako navodi Jakovčević (2012, str. 23) društva za osiguranje institucionalno i na razini razvoja proizvoda blisko surađuju s bankama, svojom aktivnošću i kanalima financijskog posredništva dinamiziraju gospodarsko okruženje pružajući gospodarskim subjektima, sektoru stanovništva i državi financijsku stabilnost. Povezivanje banaka s nebankovnim financijskim institucijama doprinosi razvoju i produbljivanju financijskog sektora. Jedan od načina suradnje, ali u određenim oblicima i konkurencije, između banaka i osiguravajućih društava je distribucija proizvoda osiguranja preko banaka, odnosno bankovnih osiguranja (Ćurak, 2004). Time banke nastoje što bolje iskoristiti svoje poslovnice za pružanje novih proizvoda i usluga na jednom mjestu dok u isto vrijeme proizvodi osiguranja postaju dostupniji sve većem broju klijenata po nižim prodajnim troškovima. Rad je strukturiran na sljedeći način. Nakon uvoda, u drugome dijelu rada definira se bankovno osiguranje te navode i obrazlažu prednosti i nedostaci uvođenja bankovnog osiguranja. U trećem se dijelu daje pregled razvijenosti bankovnog osiguranja u izabranim državama. Razvijenost tržišta osiguranja te analiza tržišta bankovnog osiguranja u Republici Hrvatskoj daje se u četvrtome dijelu. Peti, završni dio, predstavlja zaključna razmatranja do kojih se došlo u radu.

\section{Teorijske značajke bankovnog osiguranja kao modela suradnje banaka i osiguravajućih društava}

U znanstvenoj i stručnoj literaturi postoje brojne definicije bankovnog osiguranja. Prema Ćurak i Jakovčević (2007, str. 203) bankovno osiguranje podrazumijeva distribuciju proizvoda osiguranja putem banaka i jedan je od oblika sve izraženije konvergencije između bankovne i osigurateljne industrije. Bankovno 
osiguranje u užem smislu obuhvaća distribuciju proizvoda životnog osiguranja preko banaka, a u širem smislu model integracije bankovnog i osigurateljnog tržišta, s ciljem nadzora nad cjelovitim procesom proizvodnje i distribucije životnog i neživotnog osiguranja (Prga i Segedi, 2003, str. 56). Za Andrijašević i Račić-Žlibar (1997, str. 24) bankovno osiguranje označava povezivanje banaka i osiguratelja kroz prodaju osiguranja putem banaka. Ono se u većini slučajeva definira kao prodajni kanal koji predstavlja alternativu tradicionalnoj prodajnoj mreži zastupnika i posrednika u osiguranju, a u najjednostavnijem obliku označava distribuciju osigurateljnih proizvoda putem banaka. Bankovno osiguranje se može definirati i kao zajedničko nastojanje banaka i osiguravatelja u pružanju osigurateljnih usluga klijentima banaka. Navedena definicija naglašava sljedeće: (1) distribucija osiguranja nije ograničena samo na poslovnice banaka, (2) isključeno je pružanje financijskih (bankovnih) usluga od strane osiguravatelja, (3) uključena je distribucija integriranih financijskih proizvoda sve dok proizvodi sadrže komponentu osiguranja (Swiss Re, 2007, str. 5). Jakovčević (2012) smatra kako je danas bankovno osiguranje komplementarni zajednički proizvod banaka i osiguravajućih društava. U užem smislu predstavlja kanal za distribuciju životnog osiguranja preko banaka, a u širem smislu predstavlja integraciju osigurateljnog i bankovnog tržišta s pozitivnim ekonomskim učincima za banke i osiguravajuća društva.

Bertoncelj (2012) pod bankovnim osiguranjem podrazumijeva suradnju banaka i osiguravatelja čiji je cilj najbolja moguća usluga klijentima banke prilagođena njihovim zahtjevima i mogućnostima te stvaranje dodatne vrijednosti za banku, osiguravajuća društva i klijente. Bankovno osiguranje u svom najjednostavnijem obliku predstavlja distribuciju proizvoda osiguranja putem banaka, $\mathrm{tj}$. bankovno osiguranje predstavlja strategiju prihvaćenu od strane banaka i osiguravajućih društava u cilju zajedničkog nastupa na tržištu financijskih usluga (Prga i sur., 2011, str. 97). Šuper (2010) pod pojmom bankovnog osiguranja podrazumijeva novu stratešku orijentaciju financijskih institucija, banaka i osiguravajućih društava koji putem zajedničke suradnje pružaju različite financijske usluge u cilju zadovoljavanja cjelokupnih potreba klijenata. Kako navode Ćurak i Pojatina (2004) bankovno osiguranje je nastalo i razvijalo se uglavnom pod utjecajem motiva osiguratelja da ostvare niže distribucijske troškove i pristup novih kupaca svojih proizvoda, a s druge strane i banaka koje su u tome pronašle dodatni izvor provizijskog prihoda i mogućnost zadržavanja svojih klijenata. Prga i sur. (2011) smatraju kako je bankovno osiguranje na distribucijskoj razini samo početni stupanj integracije poslovanja banaka i osiguravajućih društava budući da promjene u financijskom sektoru utječu na približavanje financijskih institucija i stvaranjem financijskih konglomerata koji na jednom mjestu pružaju sve financijske usluge.

Nastojanje da se, što je moguće efikasnije i efektivnije, zadovolje potrebe i želje klijenata uvjetovalo je približavanje bankovnog i osigurateljnog sektora una- 
toč činjenici da među ovim aktivnostima postoje funkcionalne razlike. Povezanost između operativnih sektora bankarstva i osiguranja te karakteristike financijskih usluga koje su dostupne u osnovi ponude jednih i drugih, a koje se odnose na njihovu prolaznost, odsustvo opipljive dimenzije, snažnu povezanost s preciznim sporazumima i ugovorima, doprinijele su integriranju ovog područja, prije svega u nastojanju da se osigura ponuda financijskih usluga usmjerena aktualnim i potencijalnim klijentima (Babić Hodović, 2003, str. 60).

Kod same distribucije proizvoda osiguranja putem banaka važno je razlikovati poslovanje s proizvodima neživotnih osiguranja od proizvoda životnih osiguranja. Prema Duplančić Frani (2004) razlozi uspješnosti bankovnog osiguranja u industriji životnih osiguranja su mnogobrojni, a najvažniji su: (1) banke raspolažu rasprostranjenom mrežom poslovnica preko kojih se mogu prodavati proizvodi životnih osiguranja, (2) banke imaju česte kontakte sa svojim klijentima čemu doprinosi brža tehnologija vođenja bankovnih usluga, a prodaja osiguranja ovim putem sprječava daljnji gubitak kontakta sa klijentima, (3) banke mogu koristiti puno detaljniju bazu podataka za pristup kupcima nudeći im proizvod kreiran po njegovim mjerilima, (4) banke uglavnom imaju bolju reputaciju jer predstavljaju „,institucije od povjerenja“ za razliku od osiguravajućih društava koja se doživljavaju kao obični prodavači, (5) bankovno osiguranje se smatra mnogo učinkovitijim u odnosu na klasičnu prodaju osiguranja, (6) bankovno osiguranje predstavlja novinu u poslovanju osiguravajućih društava jer pobuđuje veliku pažnju klijenata rezultirajući mnogo jednostavnijim i transparentnijim proizvodima namijenjenima širokoj srednjoj klasi. Klunić (2014) navodi kako su proizvodi neživotnih osiguranja tradicionalno slabije zastupljeni u bankovnom osiguranju, a glavni razlog tome je komplementarna priroda proizvoda životnih osiguranja i bankovnih proizvoda. Iako je prema Prgi i Segedi (2003) vidljivo da banke ulaze u poslove neživotnog osiguranja, smatraju kako je interes banaka za taj segment u načelu bio slab jer je zahtijevao da se nauči posve novi posao koji donosi mogućnost visokih odštetnih zahtjeva, rizik utjecaja na reputaciju te problem održavanja visoke razine usluga i interesa klijenata da sve obave na jednom mjestu. Proizvodi neživotnih osiguranja u bankovnom osiguranju su tradicionalno manje popularni, za razliku od proizvoda životnih osiguranja. Glavni razlog tome je nadopunjujuća priroda životnih i bankovnih proizvoda. S druge strane, ovaj argument je u kontradikciji s bankovnom prodajom proizvoda životnog osiguranja, obzirom da su klijenti ista ciljna skupina za bankovne proizvode (oročeni depoziti, štednja, uzajamni proizvodi). Životno osiguranje kao ugovor dugoročnog karaktera zahtjeva instituciju od povjerenja što banke doista jesu. Bankovni osiguratelji također imaju mogućnosti uspješno djelovati u sektoru neživotnih osiguranja u slučaju proizvoda koji su povezani sa bankovnim uslugama, a u prvom redu se to odnosi na police za osiguranje imovine koja je dana kao hipoteka za zajam. Mogućnost sinergije iz- 
među banaka i osiguravatelja veća je u životnim nego u neživotnim osiguranjima jer troškovi distribucije čine daleko veći udjel u ukupnim troškovima kod životnih nego kod neživotnih osiguranja (Duplančić Frana, 2004).

Uvođenje bankovnog osiguranja pruža brojne prednosti i za banke i za osiguravajuća društva, ali u isto vrijeme povezivanje banaka s osiguravajućim društvima putem bankovnog osiguranja ima i određene troškove i rizike. Bertoncelj (2012) smatra kako bankama bankovno osiguranje predstavlja izvor novih nekamatnih prihoda i priliku za diverzifikaciju poslovanja. Prema Ćurak i Jakovčević (2007, str. 205) banke putem bankovnom osiguranja imaju mogućnost pristupa velikom broju korisnika financijskih usluga zbog široko rasprostranjene mreže poslovnica. Dodatno povećanju profitabilnosti iz obavljanja poslova bankovnog osiguranja doprinosi i odnos banke s klijentima te reputacija koju banke imaju kod značajnog dijela korisnika financijskih usluga, a koja pozitivno djeluje i na kupnju proizvoda osiguranja ponuđenih u poslovnicama banaka (Ćurak i Pojatina, 2004). Kako navodi Rosanda (2008) banke kroz razvoj bankovnog osiguranja dobivaju mogućnost iskorištavanja resursa koji bi inače bili neiskorišteni, priliku za povećanje lojalnosti klijenata te mogućnost integracije portfelja proizvoda neophodnih za bolje i potpunije zadovoljavanje potreba klijenata. Kramarić Pavić (2005) navodi kako bankovno osiguranje privlači osiguravatelje jer mogu pristupiti golemoj bančinoj bazi podataka o klijentima, smanjiti ovisnost o tradicionalnim zastupnicima i posrednicima u osiguranju koristeći različite bankovne kanale, dijeliti usluge $\mathrm{s}$ bankama, učinkovitije razvijati nove financijske proizvode u suradnji s bankama partnerima, brzo uspostaviti prisutnost na tržištu bez potrebe za stvaranjem mreže zastupnika i posrednika u osiguranju, prikupiti dodatni kapital od banaka radi poboljšanja solventnosti i proširenja poslovanja. Prema Rosandi (2008) prednosti bankovnog osiguranja za osiguravajuća društva su iskorištavanje prodajnog kanala banaka bez potrebe dodatnog ulaganja u razvoj novog prodajnog kanala, pristup dijelu klijenata koji im do sada nisu bili atraktivni i/ili koje nisu bili u stanju dosegnuti te mogućnost korištenja ključnih prodajnih i marketinških iskustava u novom okruženju.

Konvergencija između banaka i osiguravatelja dovodi do veće konkurentnosti, učinkovitosti, ekonomije obujma, a što je najvažnije za klijenta - do većeg izbora. Klijenti će uglavnom imati koristi od nižih premija i kvalitetnije usluge. Obzirom da su distribucijski troškovi niži nego kod tradicionalnih kanala prodaje, to će imati za posljedicu sniženu premiju osiguranja koju mora platiti osiguranik. Dodatno, način plaćanja premije osiguranja je pojednostavljen budući da se plaćanje može vršiti izravno sa bankovnog računa osiguranika (SCOR Group, 2005). Klijenti se mogu smatrati najvažnijom karikom „,zadovoljnog trokuta“. Ponudom bankovnog osiguranja klijent je dobio proizvod koji zadovoljava sve njegove kriterije - brza i raznovrsna usluga na jednom mjestu (Jakovčević, 2000). Bankovno 
osiguranje omogućava razvijanje novih proizvoda koji su bolje prilagođeni potrebama klijenata i koji se možda ne bi mogli nabaviti da banke i osiguravajuća društva djeluju samostalno. Primjeri novih proizvoda su osiguranje prekoračena po računu, osiguranje deponenta, zajmovi na temelju police osiguranja, zajmovi na temelju police osiguranja života i drugi proizvodi koji se prodaju u sklopu bankovnih usluga, a što u konačnici povećava zadovoljstvo osiguranika (Šuper, 2010).

Rizik povezivanja bankovnog sektora i osiguravajućih društava vezan je za organizacijsku kompleksnost i troškove novonastalih subjekata. Oni su usko povezani s djelovanjem informacijskih sistema svakog od partnera, obukom osoblja za djelovanje u različitim distributivnim kanalima, različitim shvaćanjem marketinga, potrebom korištenja različitih marketinških strategija i taktika u nastupu na pojedinim tržišnim segmentima, kao i opasnošću od gubitka postojećih klijenata (Babić Hodović, 2003). S uvođenjem aktivnosti bankovnog osiguranja povezani su, prije svega, početni troškovi uspostavljanja, koji se primarno odnose na troškove koordiniranja i reorganiziranja aktivnosti, prilagodbe informacijskih sustava i osposobljavanja zaposlenika. Korištenje informatičke opreme u poslovnicama banaka za prodaju proizvoda osiguranja može uzrokovati ekonomije cilja, za izvršenje ovih aktivnosti nužna je prilagodba programskog dijela informacijskog sustava (Ćurak i Jakovčević, 2007). Također, obzirom na nedovoljno poznavanje i specifičnost proizvoda osiguranja, njihova prodaja posredstvom banaka zahtjeva edukaciju osoblja zaposlenog u poslovnicama banaka. Troškovi osposobljavanja zaposlenika ograničavaju korištenje bankovnog osiguranja samo za jednostavnije proizvode osiguranja. Razlike u kulturama, odnosno pristupima poslovanju banaka i osiguravatelja, stvaraju teškoće u komunikaciji i implementaciji poslova i potencijalni su izvor disekonomija iz aktivnosti bankovnog osiguranja. Bankovna prodajna filozofija je tradicionalno defanzivna, a osigurateljna agresivna (Ćurak i Pojatina, 2004).

Čak i pod pretpostavkom da su banka i osiguravajuće društvo odlučili ući u bankovno osiguranje, postoje brojna ograničenja koja treba savladati tijekom njegove primjene. Prema Mašiću (2003, str. 19) najčešći faktori neuspjeha su loše upravljanje ljudskim resursima, nedostatak kulture prodaje osoblja u banci, neuključivanje voditelja poslovnice, otpor prema promjenama, nedovoljna integriranost marketinških planova, neodgovarajuće nagrađivanje i poticanje te slaba povezanost prodajnih kanala. Prga i Segedi (2003) navode kako su jedan od temeljnih nedostataka bankovnog osiguranja složeni proizvodi, s opcijama koje zbunjuju i prodavatelja, ali i klijente. Stoga, bankovno osiguranje, u načelu, treba pojednostavljivati proizvode. 


\section{Analiza tržišta bankovnog osiguranja u svijetu}

Iako je bankovno osiguranje privuklo pozornost tek u novije doba, još od 19. stoljeća bankovne i osigurateljne usluge nudile su CGER u Belgiji, La Caixa u Španjolskoj i CNP u Francuskoj (Genetay i Molyneux, 1998). Počeci bankovnog osiguranja vezani su uz promjene zakona u Francuskoj 1984. godine kojim je bankama omogućeno širenje i na tržište osiguranja. Već 1990. godine udjel bankovnog osiguranja u Francuskoj čini $39 \%$ od ukupno zaračunate premije životnih osiguranja, a u 2000. godini čak $61 \%$ (Klasić, 2004). Prema Genatay i Molyneux (1998) evolucija bankovnih osigurateljnih proizvoda podijeljena je na tri faze: (1) prije 1980. godine banke su prodavale jamstvo osiguranja kao dodatak na svoje aktivnosti (osiguranje kredita koje se nudilo uz potrošačke i druge kredite, posredovanje kod polica osiguranja zbog hipotekarnih kredita, osiguranje od krađe prigodom podizanja novca). Takve aktivnosti još se nisu smatrale bankovnim osiguranjem, (2) oko 1980. godine nastaje pravo bankovno osiguranje uz razvoj financijskih proizvoda (štedni proizvodi s povoljnim poreznim tretmanom povezani sa životnim osiguranjem kod kojih se svota isplaćuje nakon fiksnog razdoblja), (3) krajem osamdesetih godina pojavljuju se nastojanja da se iskoristi sinergija dviju aktivnosti, zatim inovacije, proširena ponuda osigurateljnih proizvoda preko banaka prema potrebama klijenata. Bankovno osiguranje karakterizira neravnomjeran stupanj razvoja u svijetu što je vidljivo iz tablica 1 i 2 .. Za razliku od europskog tržišta koje ima najveće stope rasta bankovnog osiguranja, udjel bankovnog osiguranja na tržištu Sjeverne Amerike, uključujući Sjedinjene Američke Države i Kanadu, značajno je niži što je posljedica prijašnjih restriktivnih mjera koje su onemogućavale prodaju osiguranja putem banaka, ali i javne svijesti, sklonosti i podjele između banaka i osiguravajućih društava. Percepcija niske profitabilnosti proizvoda osiguranja u odnosu na bankovne proizvode također je obeshrabrila banke u prodaji proizvoda osiguranja (Swiss Re, 2007). 
Tablica 1.

UDJEL BANKOVNOG OSIGURANJA KAO DISTRIBUCIJSKOG KANALA U UKUPNOJ ZARAČUNATOJ PREMIJI ŽIVOTNIH OSIGURANJA OSIGURAVAJUĆIH DRUŠTAVA U IZABRANIM DRŽAVAMA 2009. GODINE (\%)

\begin{tabular}{|l|c|c|c|c|}
\hline \multirow{2}{*}{ Država } & \multicolumn{4}{|c|}{ Distribucijski kanal prodaje životnih osiguranja } \\
\cline { 2 - 5 } & Bankovno osiguranje & Agenti & Brokeri & Ostali \\
\hline Australija & 43 & - & 57 & - \\
\hline Brazil & 55 & - & 30 & - \\
\hline Kanada & 1 & 50 & 34 & 5 \\
\hline Čile & 13 & - & 87 & - \\
\hline Kina & 16,3 & - & 83,7 & - \\
\hline Malezija & 45,3 & 49,4 & 2,4 & 2,9 \\
\hline Meksiko & 10 & - & 90 & - \\
\hline Tajvan & 33 & 11,7 & 6,6 & 48,7 \\
\hline SAD & 2 & - & - & - \\
\hline
\end{tabular}

Izvor: European insurance and reinsurance federation (2010)

Tablica 2.

UDJEL BANKOVNOG OSIGURANJA KAO DISTRIBUCIJSKOG KANALA U UKUPNOJ ZARAČUNATOJ PREMIJI NEŽIVOTNIH OSIGURANJA OSIGURAVAJUĆIH DRUŠTAVA U IZABRANIM DRŽAVAMA 2009. GODINE (\%)

\begin{tabular}{|l|c|c|c|c|}
\hline \multirow{2}{*}{ Država } & \multicolumn{4}{|c|}{ Distribucijski kanal prodaje neživotnih osiguranja } \\
\cline { 2 - 5 } & Bankovno osiguranje & Agenti & Brokeri & Ostali \\
\hline Australija & - & 21 & 74 & 5 \\
\hline Brazil & 13,3 & - & 71,6 & - \\
\hline Kanada & - & 18 & 74 & 8 \\
\hline Čile & 18,8 & - & 81,2 & - \\
\hline Kina & - & 45,4 & 2 & 52,6 \\
\hline Japan & - & 92,8 & 0,2 & 7 \\
\hline Malezija & 10 & 40 & 23 & 27 \\
\hline Meksiko & 10 & 25 & 50 & 15 \\
\hline Tajvan & - & 62 & 30 & 8 \\
\hline
\end{tabular}

Izvor: European insurance and reinsurance federation (2010) 
Sučić (2012) navodi kako je svjetska poslovna praksa pokazala da je razvijenost tržišta ključan čimbenik uspjeha u povezivanju banaka i osiguravatelja. U onim državama gdje je tržište tradicionalnih kanala (interni djelatnici, agencije) izrazito razvijeno, bankovno osiguranje se razvijalo sporije, za razliku od nerazvijenih, ali brzo rastućih tržišta (npr. Azije i Pacifika), gdje se bankovno osiguranje razvijalo znatno brže. Razlog tome je činjenica da je na tržište najlakše ući preko već izgrađene mreže poslovnica, a u slučaju sektora osiguranja, to je najlakše putem banaka.

Prema Davisu (2007) percepcija potrošača još je jedan dodatan razlog za marginalni uspjeh banaka u prodaji proizvoda osiguranja u Sjedinjenim Američkim Državama. Oni većinom proizvode i usluge osiguranja kupuju putem agenata, a mnogi od njih ne znaju da banke prodaju proizvode osiguranja ili skeptično gledaju prema prodaji osiguranja putem bankovnih poslovnica. Prodaja osiguranja donosila je 2005. godine američkim bankama samo 6,6\% nekamatnih prihoda. Dominantan proizvod prodaje američkih bankovnih osiguratelja je bilo rentno osiguranje, sa $42 \%$ udjelom u ukupnoj prodaji 2005. godine. U Sjedinjenim Američkim Državama ti proizvodi imaju povoljan porezni tretman.

Australija ima visoki udjel bankovnog osiguranja na tržištu životnih osiguranja što je posljedica akvizicija mnogobrojnih osiguravajućih društava za prodaju životnih osiguranja od strane bankovnih grupacija. Udjel banaka u prodaji proizvoda životnog osiguranja 2006. godine je bio $43 \%$. Tržišta u razvoju imaju različite stope rasta bankovnog osiguranja što uvelike ovisi o lokalnim regulatornim okvirima te utjecaju drugih društvenih i kulturnih pitanja. Najveći napredak u razvoju bankovnog osiguranje je ostvarilo na tržištima azijskih zemalja, uglavnom na tržištu životnih osiguranja. Financijska deregulacija omogućila je pojavu i razvoj bankovnog osiguranja, a samim time i zainteresiranost inozemnih osiguravajućih društava za uspostavu suradnje sa domaćim bankama. Udjel bankovnog osiguranja u prodaji životnih osiguranja 2006. godine iznosio je 8,5 \% u Južnoj Koreji, 16,3 \% u Kini, Tajvanu $33 \%$ te čak 45,3\% u Maleziji. U isto vrijeme bankovno osiguranje bilježi uspjeh i u srednjoj i istočnoj Europi kao i u Latinskoj Americi gdje su se inozemna osiguravajuća društva uglavnom usmjerila na lokalne banke koje imaju dobru teritorijalnu rasprostranjenost i s kojima žele ostvariti partnerstvo ili ih jednostavno žele preuzeti (Swiss Re, 2007).

Osiguratelji prodaju svoje proizvode izravno ili putem drugih prodajnih kanala, od koji su najpoznatiji brokeri, agencije i bankovno osiguranje. Značaj svakog od prodajnog kanala bitno se razlikuje ovisno o tržištu ili proizvodu (Insurance Europe, 2017). Prema podacima iz tablice 3., bankovno osiguranje je u promatranom razdoblju najvažniji prodajni kanal životnih osiguranja na velikim tržištima kakva su u Turskoj (81,2 \%), Portugalu (78,7 \%), Italiji (75,8 \%), Francuskoj (64\%). 
Tablica 3 .

UDJEL ZARAČUNATE PREMIJE PUTEM BANKOVNOG OSIGURANJA U UKUPNOJ PREMIJI ŽIVOTNIH OSIGURANJA U IZABRANIM DRŽAVAMA, 2007. - 2013. GODINE (\%)

\begin{tabular}{|l|c|c|c|c|c|c|c|}
\hline \multicolumn{1}{|c|}{ Država } & 2007. & 2008. & 2009. & 2010. & 2011. & 2012. & 2013. \\
\hline Hrvatska & 18,7 & 17,6 & 16,1 & 18,4 & 19,3 & 20,1 & 23,3 \\
\hline Italija & 66,3 & 62,5 & 74,4 & 76,3 & 73,1 & 71,9 & 75,8 \\
\hline Francuska & 62,0 & 60,0 & 60,0 & 61,0 & 61,0 & 63,0 & 64,0 \\
\hline Poljska & 23,4 & 44,4 & 32,6 & 28,3 & 30,0 & 38,9 & - \\
\hline Španjolska & 72,3 & - & 66,2 & 69,0 & 71,4 & 69,7 & 63 \\
\hline Portugal & 87,3 & 81,6 & 82,7 & 84,2 & 82,0 & 77,8 & 78,7 \\
\hline Turska & 50,6 & 46,0 & 56,4 & 69,5 & 75,2 & 77,4 & 81,2 \\
\hline Austrija & 53,9 & 51,7 & 64,8 & 62,6 & 51,7 & 45 & 48,1 \\
\hline Belgija & 42,7 & 42,3 & 42,4 & 43,2 & 44,0 & 47,1 & 32,8 \\
\hline
\end{tabular}

Izvor: Obrada autora prema Insurance Europe (2016)

U Francuskoj se značajni razvoj distribucije osigurateljnih proizvoda putem bankovnih poslovnica javlja tijekom osamdesetih godina prošlog stoljeća, kao posljedica osnivanja društava za životna osiguranja u vlasništvu velikih banaka (Matijević, 2010). Kako navode Genetay i Molyneux (1998), za Francusku je bilo karakteristično to da je tržište životnog osiguranja bilo nešto slabije razvijeno nego u drugim zemljama što je olakšalo nastup banaka koje su u tome vidjele način da iskoriste svoje brojne poslovnice. Konkurencija među osigurateljima je bila nešto slabije razvijena i važnu ulogu u tome imale su obvezne vrste osiguranja. Ujedno je upravo konkurencija među bankama ubrzala njihov ulazak u taj dio poslovanja. Broj agenata, koji su do tada gotovo imali monopol u prodaji osiguranja, bitno je smanjen ulaskom banaka na tržište.

Razvoj bankovnog osiguranja u Španjolskoj razlikuje se od drugih europskih zemalja budući da je španjolskim bankama bilo dopušteno vlasničko ulaganje u osiguravajuća društva, kao i prodaja osigurateljnih proizvoda (Šuper, 2010). Razvoj bankovnog osiguranja počeo je reformom marketinga životnih osiguranja. Karakteristična je bila slaba razvijenost osiguravajućeg tržišta koje je bankama omogućilo da iskoriste već postojeće vlasničke veze s osigurateljima te niže premije životnih osiguranja po stanovniku za razliku od ostalih zapadnoeuropskih zemalja. Od 1980. godine, španjolsko tržište osiguranja ima najviše stope rasta 
premije osiguranja u Europi (SCOR Group, 2005). U početku je bankovno osiguranje krenulo ponudom polica s jednokratnom premijom i poreznim olakšicama, a kasnije su banke ponudile i razne vrste neživotnih osiguranja.

Glavni prodajni kanali neživotnih osiguranja u europskim državama su agencije i brokeri (Insurance Europe, 2017) dok distribucija proizvoda osiguranja putem banaka ima puno manje značenje (tablica 4).

\section{Tablica 4.}

UDJEL ZARAČUNATE PREMIJE PUTEM BANKOVNOG OSIGURANJA U UKUPNOJ PREMIJI NEŽIVOTNIH OSIGURANJA U IZABRANIM DRŽAVAMA, 2007. - 2013. GODINE (\%)

\begin{tabular}{|l|r|r|r|r|r|r|r|}
\hline \multicolumn{1}{|c|}{ Država } & 2007. & 2008. & 2009. & 2010. & 2011. & 2012. & 2013. \\
\hline Hrvatska & 1,0 & 1,4 & 1,6 & 2,3 & 2,7 & 3,1 & 3,4 \\
\hline Italija & 1,8 & 2,3 & 3,1 & 3,3 & 3,5 & 3,3 & 3,6 \\
\hline Francuska & 9,0 & 10,0 & 10,0 & 11,0 & 11,0 & 12,0 & 13,0 \\
\hline Poljska & 1,4 & 2,1 & 3,5 & 4,9 & 2,2 & 2,3 & - \\
\hline Śpanjolska & 11,5 & - & 8,8 & 9,7 & 10,2 & 10,1 & 10,5 \\
\hline Portugal & 10,0 & 9,9 & 12,8 & 12,8 & 14,0 & 15,3 & 10,2 \\
\hline Turska & 10,9 & 11,7 & 12,1 & 13,3 & 13,6 & 14,1 & 14,0 \\
\hline Austrija & 4,6 & 54,4 & 54,4 & 5,4 & 5,7 & 5,7 & 6,1 \\
\hline Belgija & 6,1 & 6,3 & 6,8 & 6,9 & 7,2 & 7,5 & 7,6 \\
\hline
\end{tabular}

Izvor: Obrada autora prema Insurance Europe (2016)

\section{Analiza tržišta bankovnog osiguranja u Republici Hrvatskoj}

Prema podacima Hrvatskog ureda za osiguranje (2017a), poslovne banke su na kraju rujna 2016. godine imale 69,6\% udjela u strukturi financijskih institucija, obvezni mirovinski fondovi 14,43 \%, a osiguravajuća društva 7,05 \% udjela. U skladu s takvom strukturom, Leko (2012) navodi kako je Republika Hrvatska primjer nerazvijene, izrazito bankocentrične strukture strukture financijskog sektora u kojem poslovne banke dominiraju u odnosu na nebankovne financijske institucije. 
Međunarodna usporedivost i značaj društava za osiguranje i djelatnosti osiguranja prikazuju tri ključna pokazatelja: (1) udjel premije osiguranja u bruto društvenom proizvodu ili osigurateljna penetracija, (2) premija osiguranja po osiguraniku ili osigurateljna gustoća, (3) udjel premije životnog osiguranja u ukupnoj premiji osiguranja (Hrvatski ured za osiguranje, 2017a). Razvijene zemlje i razvijena tržišta osiguranja karakterizira udjel premije osiguranja u BDP-u iznad 7 \%, godišnja ulaganja u osiguranje po stanovniku više od 2.000 USD i udjel premije životnog osiguranja u ukupnoj premiji iznad $45 \%$. Ovi pokazatelji za hrvatsko tržište osiguranja su na kraju 2015. godine iznosili: 2,6\% udjel premije u BDP-u, 299 USD ili 2.091 kuna premije osiguranja po stanovniku te udjel premije životnog osiguranja u ukupnoj premiji od 33,5\%. Svi pokazatelji ukazuju na značajan prostor za rast premije osiguranja u Republici Hrvatskoj, posebno u usporedbi sa državama članicama Europske unije i zemljama europodručja (Hrvatski ured za osiguranje, 2017a).

Poslovni odnos banaka i osiguratelja u hrvatskom financijskom sustavu je u početnoj fazi razvoja. Primarni razlozi nerazvijenosti nalaze se u nedovoljnoj konkurenciji koja nije stvarala potrebu za poslovima banaka izvan tradicionalnog posredništva te u niskoj razvijenosti osiguranja (Šuper, 2010, str. 97).

Globalna ekspanzija bankovnog osiguranja je krajem 1990-ih godina počela utjecati i na banke i osiguravajuća društva u Republici Hrvatskoj. Za razliku od konvergencije između banaka i osiguravajućih društava u razvijenim financijskim sustavima koja doseže visoki stupanj, u hrvatskom financijskom sustavu ona tek poprima razvojne početke. Najčešći oblik funkcionalne povezanosti između banaka i osiguravajućih društava u hrvatskom financijskom sustavu su sporazumi o distribuciji proizvoda osiguranja putem banaka (Šuper, 2010, str. 97). Kako navodi Bertoncej (2012) razvoj bankovnog osiguranja je u Republici Hrvatskoj počeo krajem 1990.-ih godina. Tadašnji Adriatic osiguranje d.d., u većinskom vlasništvu Zagrebačke banke d.d., oprezno je započelo s prodajom životnih osiguranja kroz Zagrebačku banku d.d. 1996. godine. Kasnije su sa suradnjom započeli Raiffeisenbank Austria d.d. Zagreb i Uniqa osiguranje d.d., Hypo Alpe-Adria-Bank d.d. i Grawe Hrvatska d.d., Privredna banka Zagreb i Generali osiguranje d.d., Erste\&Steiermärkische Bank d.d. i Kvarner Vienna Insurance Group d.d. 
Tablica 5 .

PRIMJERI PARTNERSTVA OSIGURAVAJUĆIH DRUŠTAVA I BANAKA U REPUBLICI HRVATSKOJ

\begin{tabular}{|l|l|}
\hline \multicolumn{1}{|c|}{ Osiguravajuće društvo } & \multicolumn{1}{c|}{ Banka } \\
\hline \multirow{4}{*}{ Generali osiguranje d.d. } & Privredna banka Zagreb d.d. \\
\cline { 2 - 2 } & Istarska kreditna banka d.d. \\
\cline { 2 - 2 } & Podravska banka d.d. \\
\cline { 2 - 2 } & Imex banka d.d. \\
\hline Agram life osiguranje d.d. & Kreditna banka Zagreb d.d. \\
\hline Uniqa osiguranje d.d. & Raiffeisenbank Austria d.d. Zagreb \\
\hline BNP Paribas Cardif osiguranje d.d. & Privredna banka Zagreb d.d. \\
\hline Erste osiguranje Vienna Insurance Group d.d. & Erste\&Steiermärkische Bank d.d \\
\hline Allianz Zagreb d.d. & Zagrebačka banka d.d. \\
\hline \multirow{5}{*}{ Croatia osiguranje d.d. } & Privredna banka Zagreb d.d. \\
\cline { 2 - 3 } & Hrvatska poštanska banka d.d. \\
\cline { 2 - 3 } & Zagrebačka banka d.d. \\
\cline { 2 - 2 } & Addiko bank d.d. \\
\cline { 2 - 2 } & Slatinska banka d.d. \\
\cline { 2 - 2 } & Croatia banka d.d. \\
\cline { 2 - 2 } & Imex banka d.d. \\
\cline { 2 - 2 } & Karlovačka banka d.d. \\
\cline { 2 - 2 } & BKS bank d.d. \\
\cline { 2 - 2 } & OTP banka d.d. Hrvatska \\
\hline
\end{tabular}

Izvor: Obrada autora prema Šuper (2010)

Hrvatsko tržište bankovnog osiguranja ne karakterizira isključivo suradnja na temelju sporazuma o distribuciji proizvoda osiguranja, nego je do pomaka u razvoju bankovnog osiguranja došlo zajedničkim ulaganjem dviju povezanih strana (Klunić, 2014). Prema Bertoncelj (2012) prvo društvo za osiguranje na hrvatskom tržištu osnovano isključivo s namjerom prodaje svojih proizvoda putem banaka bilo je Erste Sparkassen osiguranje d.d. (danas Erste osiguranje Vienna Insurance Group d.d.) koje je 2005. godine započelo s prodajom životnih osiguranja u Erste\&Steiermärkische Bank d.d. Nakon toga je započelo osnivanje i drugih društava koja su orijentirana isključivo na bankovno osiguranje (Cardif osiguranje d.d., Victoria životno osiguranje d.d., Victoria osiguranje d.d, Societe Generale osiguranje d.d.). Osnovna pretpostavka prodaje proizvoda osiguranja putem ba- 
naka u Republici Hrvatskoj koja se odnosi na regulativnu dozvolu, ispunjena je propisivanjem obavljanja ostalih financijskih usluga od strane banaka među kojima se nalazi pružanje usluga posredovanja i zastupanja u prodaji polica osiguranja (Ćurak i Pojatina, 2004).

U Republici Hrvatskoj osiguravajuća društva prodaju svojih proizvoda i usluga vrše preko vlastitih zaposlenika (bez provizije), internih zastupnika, agencija, brokera, bankovnog osiguranja te ostalih kanala distribucije. Najzastupljeniji kanal distribucije proizvoda osiguranju u promatranom razdoblju su interni zastupnici. Iako udjel internih zastupnika u ukupnoj distribuciji proizvoda osiguranja kontinuirano opada, i dalje su najzastupljeniji kanal distribucije proizvoda osiguranja. Na kraju 2016. godine interni zastupnici čine 34,19 \% udjela u zaračunatoj premiji, agencije 20,15\% udjela, distribucija preko vlastitih zastupnika (bez provizije) 18,21 \% dok bankovni kanal, odnosno distribucija putem banaka čini 16,49\% udjela u zaračunatoj premiji (tablica 6). Uvidom u strukturu zaračunate premije po prodajnim kanalima uočava se kako distribucija proizvoda osiguranja putem banaka, kao prodajnog kanala, sve više dobiva na važnosti.

Tablica 6.

STRUKTURA ZARAČUNATE BRUTO PREMIJE PO PRODAJNIM KANALIMA U REPUBLICI HRVATSKOJ, 2011. - 2016. GODINE (MLRD. KUNA)

\begin{tabular}{|l|c|c|c|c|c|c|c|c|c|c|c|c|}
\hline \multirow{2}{*}{$\begin{array}{c}\text { Prodajni } \\
\text { kanal }\end{array}$} & \multicolumn{2}{|c|}{$\mathbf{2 0 1 1 .}$} & \multicolumn{2}{c|}{$\mathbf{2 0 1 2 .}$} & \multicolumn{2}{c|}{$\mathbf{2 0 1 3 .}$} & \multicolumn{2}{c|}{$\mathbf{2 0 1 4 .}$} & \multicolumn{2}{c|}{$\mathbf{2 0 1 5 .}$} & \multicolumn{2}{c|}{$\mathbf{2 0 1 6 .}$} \\
\cline { 2 - 14 } & Iznos & $\%$ & Iznos & $\%$ & Iznos & $\%$ & Iznos & $\%$ & Iznos & $\%$ & Iznos & $\%$ \\
\hline Bez provizije & 1,706 & 18,66 & 1,616 & 17,8 & 2,199 & 24,23 & 1,901 & 22,21 & 1,676 & 19,21 & 1,595 & 18,21 \\
\hline Interni & 4,063 & 44,43 & 4,074 & 45,08 & 3,493 & 38,49 & 3,369 & 39,36 & 3,082 & 35,33 & 2,995 & 34,19 \\
\hline Agencije & 2,011 & 21,99 & 1,965 & 21,75 & 1,873 & 20,64 & 1,767 & 20,65 & 1,607 & 18,43 & 1,765 & 20,15 \\
\hline Brokeri & 0,377 & 4,13 & 0,428 & 4,74 & 0,452 & 4,99 & 0,273 & 3,22 & 0,615 & 7,06 & 0,768 & 8,77 \\
\hline Banka & 0,646 & 7,07 & 0,698 & 7,73 & 0,815 & 8,99 & 0,931 & 10,88 & 1,519 & 17,42 & 1,444 & 16,49 \\
\hline Ostali & 0,339 & 3,17 & 0,255 & 2,83 & 0,240 & 2,65 & 0,315 & 3,68 & 0,223 & 2,56 & 0,191 & 2,19 \\
\hline UKUPNO & $\mathbf{9 , 1 4 5}$ & $\mathbf{1 0 0}$ & $\mathbf{9 , 0 3 8}$ & $\mathbf{1 0 0}$ & $\mathbf{9 , 0 7 6}$ & 100 & $\mathbf{8 , 5 6 1}$ & $\mathbf{1 0 0}$ & $\mathbf{8 , 7 2 4}$ & $\mathbf{1 0 0}$ & $\mathbf{8 , 7 6 1}$ & $\mathbf{1 0 0}$ \\
\hline
\end{tabular}

Izvor: Obrada autora prema Hrvatski ured za osiguranje (2017b)

Prema podacima Hrvatskog ureda za osiguranje (2017a) o kanalima distribucije životnog osiguranja, tijekom 2016. godine najzastupljeniji kanal distribucije životnog osiguranja je bankovno osiguranje s $36,21 \%$ udjela u zaračunatoj premiji životnog osiguranja, zatim slijedi prodaja putem internih zastupnika $(24,29 \%)$ te 
prodaja putem agencija (21,77 \%). Najzastupljeniji kanal distribucije neživotnog osiguranja su tijekom 2016. godine bili interni zastupnici s 39,13\% udjela u zaračunatoj premiji, zaposlenici društva (bez provizije) sa $21,74 \%$ udjela te agencije s 19,34\% udjela u zaračunatoj premiji neživotnog osiguranja.

U Republici Hrvatskoj se u razdoblju od 2009. do 2015. godine kontinuirano povećavao udjel zaračunate premije putem banko banaka u ukupnoj zaračunatoj premiji, odnosno bankovno osiguranje dobiva sve više na važnosti kao prodajni kanal osiguranja, osobito životnih osiguranja (grafikon 1).

\section{Grafikon 1.}

UDJEL ZARAČUNATE PREMIJE PUTEM BANKOVNOG OSIGURANJA U UKUPNOJ PREMIJI U REPUBLICI HRVATSKOJ, 2007. - 2016. GODINE (\%)

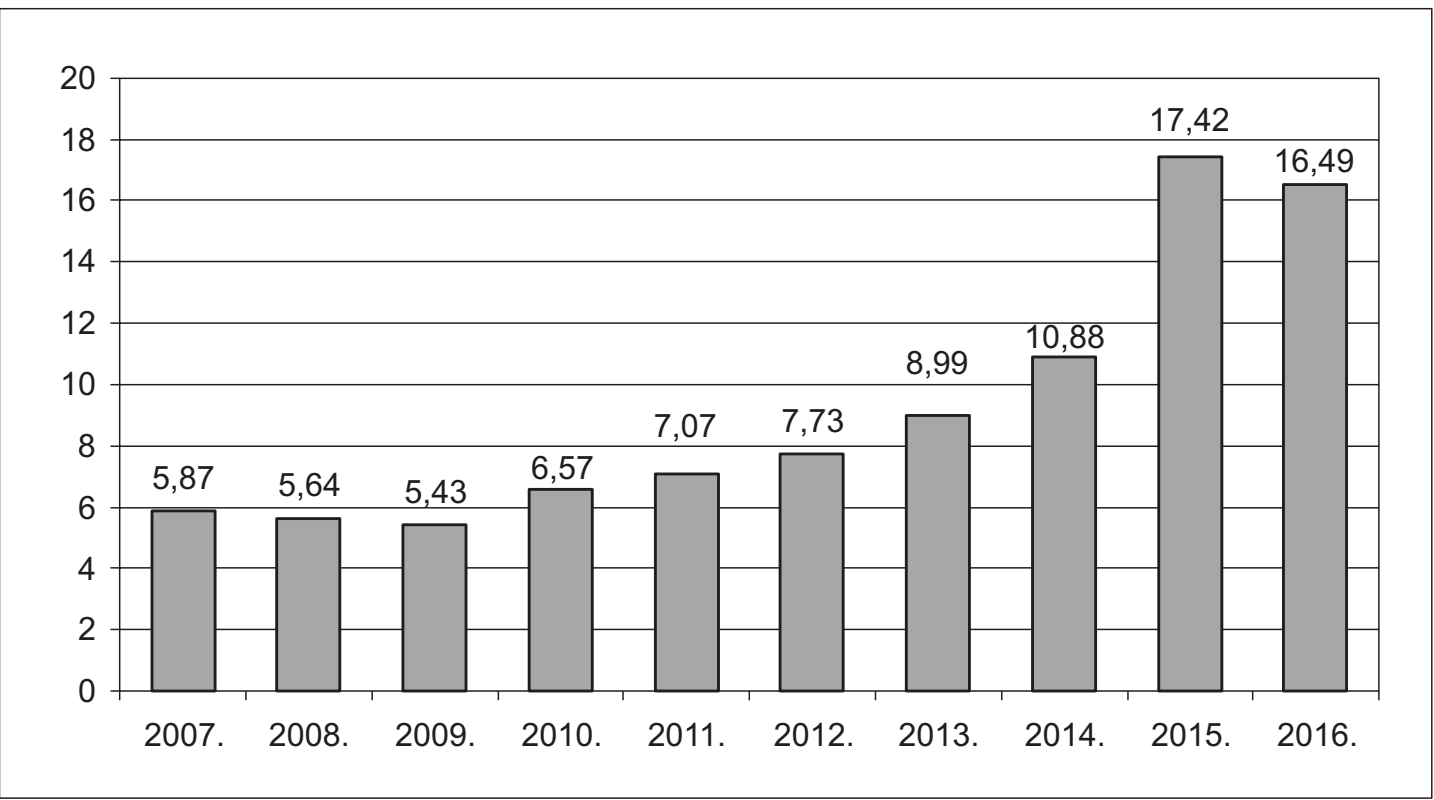

Izvor: Obrada autora prema Hrvatski ured za osiguranje (2017b)

Ako se usporedi struktura ukupno ostvarene zaračunate premije, može se zaključiti da se bankovno osiguranje u Republici Hrvatskoj brže razvija u području životnih osiguranja, a sporije u području neživotnih osiguranja što je u skladu s trendom, odnosno strukturom u ostalim državama (grafikon 2). Na kraju 2016. godine putem bankovnog prodajnog kanala ostvareno je 36,21 \% ukupno zaračunato premije u životnim osiguranjima te ostvareno $6,65 \%$ ukupne zaračunate premije neživotnih osiguranja. 
Grafikon 2.

\section{UDJEL PRODAJE ŽIVOTNIH I NEŽIVOTNIH OSIGURANJA PUTEM BANKOVNOG OSIGURANJA U UKUPNOJ PRODAJI U REPUBLICI HRVATSKOJ, 2007. - 2016. GODINE (\%)}

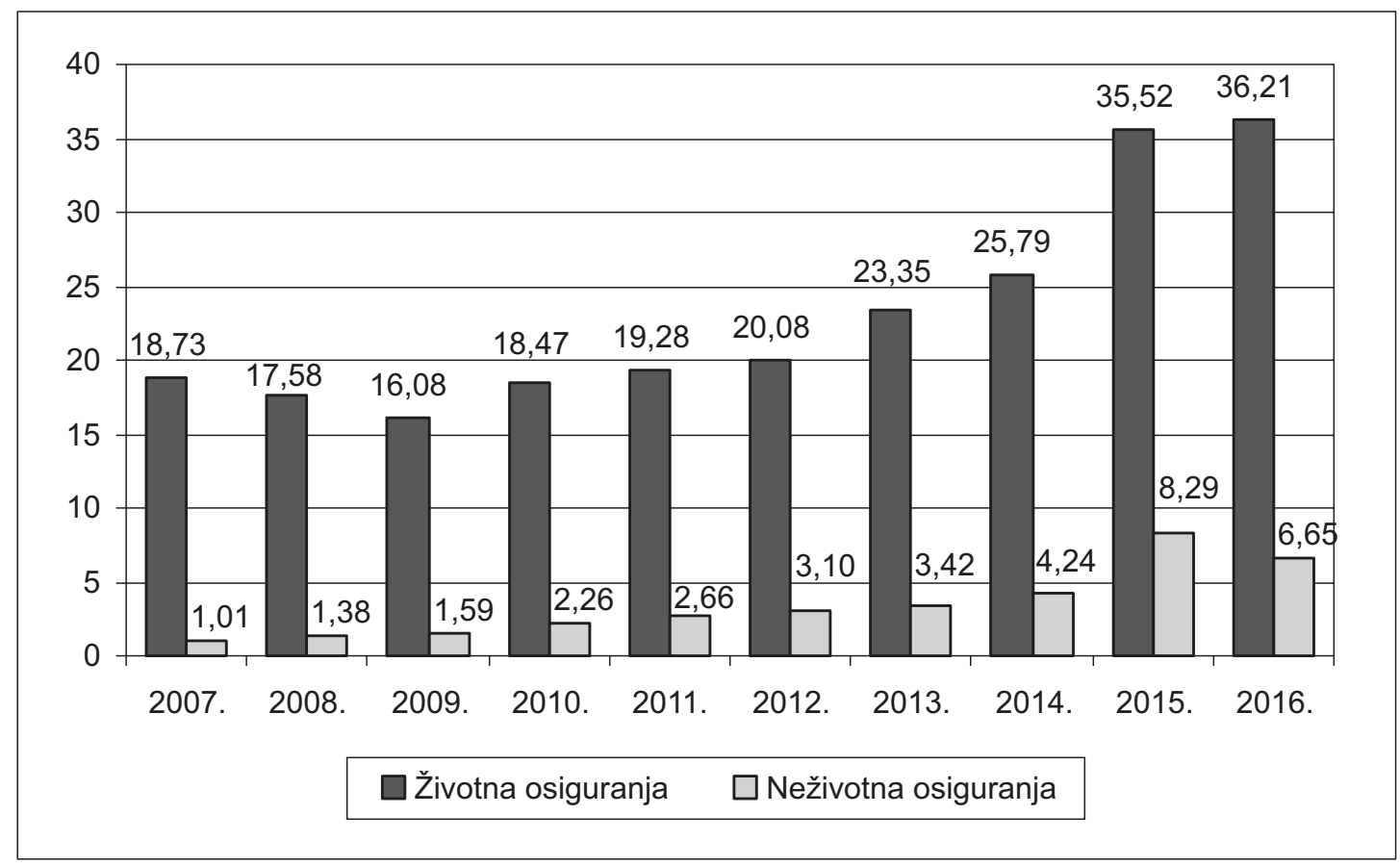

Izvor: Obrada autora prema Hrvatski ured za osiguranje (2017b)

Bertoncelj (2012) navodi kako utjecaj na razvoj bankovnog osiguranja, a također i na odabir modela suradnje, ima zakonodavni okvir koji regulira takvo poslovanje. To se prije svega odnosi na zakone koji reguliraju prodaju osiguranja putem banaka te na zakonske mogućnosti sudjelovanja banaka u dioničkoj strukturi društava za osiguranje ili osnivanja vlastitog društva za osiguranje. Također, važan poticaj razvoju bankovnog osiguranja čini povoljan porezni tretman premija. Izmjene poreznih zakona u tome smislu mogu imati pozitivan ili negativan utjecaj na prodaju proizvoda osiguranja putem banaka.

Primorac (2012) smatra da je u Republici Hrvatskoj velika slabost postojećeg modela bankovnog osiguranja ta što još uvijek ne postoji dovoljan broj profesionalnih bankovnih osiguravatelja, pa se poslom prodaje bankovnog osiguranja bave djelatnici banaka koji u bankama obavljaju i druge poslove, što znači da nisu u potpunosti orijentirani na klijenta. Bankovni službenici nemaju dovoljno znanja o 
proizvodima osiguranja, pa su potrebne stalne edukacije. Njihova edukacija mora biti takva da proizvode koje namjeravaju prodavati u potpunosti razumiju, što često nije tako. Također, nije razvijena svijest o prednostima koje osiguranje pruža te nema navike ulaganja u osiguranje te shodno tome nedovoljno je i specijaliziranih bankovnih osigurateljnih proizvoda. Nadalje, u Republici Hrvatskoj još uvijek nije razvijana svijest građana u toj mjeri da će doći u banku i kupiti samo osiguranje.

\section{Zaključak}

Bankovnim osiguranjem banka nastoji pružati svojim klijentima sve financijske usluge na jednom mjestu dok osiguranje postaje dostupnije sve većem broju potencijalnih korisnika. Kao prodajni kanal životnih i neživotnih osiguranja, bankovno osiguranje je najznačajniji razvoj ostvarilo u europskim zemljama kao što su Francuska, Italija, Portugal i Španjolska. Kod same distribucije proizvoda osiguranja putem banaka treba razlikovati poslovanje proizvodima životnih osiguranja od poslovanja proizvodima neživotnih osiguranja. Proizvodi neživotnih osiguranja su manje zastupljeni od proizvoda životnih osiguranja, a glavni razlog tome je komplementarnost bankovnih proizvoda i proizvoda životnih osiguranja. Glavni razlozi zbog kojih banke ulaze u poslove bankovnog osiguranja su izvor nekamatnih prihoda, prilika za diverzifikaciju poslovanja te mogućnost pružanja svih financijskih usluga na jednom mjestu dok je bankovno osiguranje privlačno za osiguravajuća društva jer proizvodi osiguranja, putem mreže poslovnica banaka, postaju dostupnijih sve većem broju klijenata, odnosno osiguravajuća društva time proširuju bazu postojećih klijenata. Klijenti putem bankinog prodajnog kanala mogu u banci, na jednom mjestu, dobiti i bankovnu i osigurateljnu uslugu. U Republici Hrvatskoj između banaka i osiguravajućih društava ne postoji isključivo suradnja na temelju sporazuma o distribuciji proizvoda osiguranja, već postoje i društva za osiguranje orijentirana isključivo na bankovno osiguranje. Na temelju analize razvijenosti i zastupljenosti bankovnog osiguranja, kao prodajnog kanala proizvoda osiguranja, uočava se kako bankovno osiguranje imaju puno veću zastupljenost u životnim nego u neživotnim osiguranjima u analiziranim europskim državama, ali i u Republici Hrvatskoj. Obzirom da je na europskim tržištima udjel bankovnog osiguranja, kao prodajnog kanala, u zaračunatoj premiji životnih osiguranja $60 \%$ i više, a u Republici Hrvatskoj oko 36 \%, činjenica da hrvatsko tržište osiguranja karakterizira niska penetracija i gustoća premije životnih osiguranja te bankocentričnost hrvatskog financijskog tržišta s dominantnom pozicijom poslovnih banaka ukupnoj aktivi svih financijskih institucija, tržište bankovnog osiguranja u Republici Hrvatskoj još uvijek nedovoljno nerazvijeno te ima veliki 
potencijal daljnjeg rasta. Također, na potencijal daljnjeg rasta bankovnog osiguranja u Republici Hrvatskoj utječe i činjenica kako je životno osiguranje slabije razvijeno, kako je životni standard još uvijek niži nego u razvijenim zemljama Europske unije i kako još uvijek ne postoji navika ulagati u životno osiguranje.

\section{Literatura:}

Andrijašević, S., Račić-Žlibar, T. (1997). Rječnik osiguranja. Zagreb: Masmedia.

Babić Hodović, V. (2003). "Konkurencija ili kooperacija bankarstva i osiguranja”, Svijet osiguranja, 3: 59-63.

Bertoncelj, S. (2012). "Bankoosiguranje i osigurateljno bankarstvo”, u: Jakovčević, D., Krišto, J. (Ur.), Industrija osiguranja u Hrvatskoj-promjene u okruženju, novi proizvodi, regulacija i upravljanje rizikom, Zagreb: Grafit-Gabrijel, str.83-99.

Ćurak, M. (2004). “Konvergencija između banaka i osiguravajućih društava”, Osiguranje, 3: $19-28$.

Ćurak, M., Pojatina D. (2004). “Bankoosiguranje - novi izazov”, u: Lovrinović, I., Vidučić, Lj. (Ur.), Suvremena financijska pitanja i izazovi razvitka hrvatskog financijskog sektora, Split: Ekonomski fakultet u Splitu, str.57-71.

Ćurak, M., Jakovčević, D. (2007). Osiguranje i rizici. Zagreb: RRIF.

Davis, S. (2007). Bancassurance: The Lesson of Global Experience in Banking and Insurance Collaboration. London: VRL Knowledgebank LTD.

Duplančić Frana, V. (2004). Konvergencija između banaka i osiguravatelja. Magistarski rad. Zagreb: Ekonomski fakultet u Splitu.

European insurance and reinsurance federation (2010) Insurance Distribution Channels in Europe, ožujak 2010.

Genetay, N. , Molyneux, P. (1998). Bancassurance. London: Machillan Press LTD.

Hrvatski ured za osiguranje (2017a). "Ključne informacije o tržištu osiguranja u Republici Hrvatskoj 2016.”, lipanj 2017.

Hrvatski ured za osiguranje (2017b). "Službeni podaci”. Dostupno na: https://www.huo.hr/ hrv/publikacije-i-statistika/4/ [03. rujna 2017. godine].

Insurance Europe (2016). "European Insurance in Figures - 2014 data”, srpanj 2016.

Insurance Europe (2017). "European insurance industry database - Distribution channels". Dostupno na: https://www.insuranceeurope.eu/insurancedata [03. rujna 2017. godine].

Jakovčević, D. (2012). “Značenje i uloga društva za osiguranje za financijsko i gospodarsko okruženje”, u: Jakovčević, D., Krišto, J. (Ur.), Industrija osiguranja u Hrvatskojpromjene u okruženju, novi proizvodi, regulacija i upravljanje rizikom, Zagreb: Grafit-Gabrijel, str.21-32. 
M. PLOH: Ocjena razvitka bankovnih osiguranja u Republici Hrvatskoj EKONOMSKI PREGLED, 70 (1) 112-131 (2019)

Jakovćević, T. (2000). “Bankoosiguranje”, Slobodno poduzetniš̌tvo, 12: 283-286.

Klasić, K. (2004). “Analiza tržišta bankoosiguranja u Hrvatskoj”, Svijet osiguranja, 5: 53-57.

Klunić, T. (2014). "Osiguranje života za slučaj smrti kao instrument osiguranja stambenih kredita”, Dostupno na: https://www.huo.hr/hrv/2014-godina/121/ [06. rujna 2017. godine].

Kramarić Pavić, T. (2005). "Bankoosiguranje", Osiguranje, 5: 18-26.

Leko, V. (2012). "Relativno značenje financijskih institucija", u: Jakovčević, D., Krišto, J. (Ur.), Industrija osiguranja u Hrvatskoj-promjene u okruženju, novi proizvodi, regulacija i upravljanje rizikom, Zagreb: Grafit-Gabrijel, str.3-19.

Leko, V. (2005a). "Sekuritizacijske tehnike, novi izvori financiranja i prilagodba rizika”, u: Božina, L., Leko, V., (Ur.), Novac, bankarstvo i financijska tržišta, Zagreb: Adverta, str.115-130.

Leko, V. (2005b). “Tradicionalno definiranje banaka i suvremene „full-service“ banke口”, u: Božina, L., Leko, V., (Ur.), Novac, bankarstvo i financijska tržišta, Zagreb: Adverta, str.183-192.

Mašić, N. (2003). "Bankoosiguranje”, Osiguranje, 4: 18-19.

Matijević, B. (2010). Osiguranje: management-ekonomija-pravo. Zadar: Naklada.

Prga, I. , Segedi, T. (2003). "Bankoosiguranje - model integracije bankarskog i osigurateljskog tržišta", Računovodstvo i financije, 5: 56-60.

Prga, I., Stojanović, A., Šverko, I., Škember, A., Živković Matijević, Z. (2011). Upravljanje institucionalnim investitorima: pomoćni materijali za izučavanje. Zagreb: Ekonomski fakultet Zagreb.

Primorac, I. (2012) Implementacija prakse Europske unije u pogledu bankoosiguranja u Republici Hrvatskoj. Specijalistički poslijediplomski rad. Zagreb: Ekonomski fakultet u Zagrebu.

Rosanda, P. (2008). "Osiguratelji i bankari ruku pod ruku”, Svijet osiguranja, 10: 52-55.

SCOR Group (2005). Bancassurance. Paris: SCOR.

Sučić, A. (2012). Troškovna efikasnost bankoosiguranja u odnosu na ostale kanale distribucije osiguranja. Magistarski rad. Zagreb: Ekonomski fakultet u Zagrebu

Swiss Re (2007). "Bancassurance: emergings trends, opportunities and challenges”, Sigma No.5.

Šuper, M. (2010). Bankoosiguranje u funkciji razvoja osigurateljne industrije u Republici Hrvatskoj. Magistarski rad. Zagreb: Ekonomski fakultet. 


\title{
EVALUATION OF DEVELOPMENT OF BANKING INSURANCE IN THE REPUBLIC OF CROATIA
}

\begin{abstract}
Summary
The purpose of this paper is to compare and evaluate the development of banking insurance, as a model of co-operation between banks and insurance companies in the distribution of insurance products through banks, in selected European countries and the Republic of Croatia. In addition, this paper presents theoretical features, and main advantages and disadvantages of banking insurance. Unlike developed European countries, where life insurance distributed through banks represents more than $60 \%$ of the total life insurance premium charged, in the Republic of Croatia this share is approximately $36 \%$ which clearly shows that its banking insurance is still underdeveloped and with a great potential for future growth. Also, by looking at comparable gross premium, it is evident that banking insurance in the Republic of Croatia is developing faster in the area of life insurance and noticeably slower in the non-life insurance. This is in line with trends and structures of other developed European countries.
\end{abstract}

Key words: banks, insurance companies, bank assurance, the Republic of Croatia 